\title{
Targeting ErbB2 and ErbB3 with a bispecific single-chain Fv enhances targeting selectivity and induces a therapeutic effect
} in vitro

\author{
MK Robinson*,', KM Hodge', E Horak', ÅL Sundberg', M Russeva', CC Shaller', M von Mehren', I Shchaveleva', \\ HH Simmons', JD Marks ${ }^{2}$ and GP Adams*,
}

'Department of Medical Oncology, Fox Chase Cancer Center, Philadelphia, PA, USA; '2Department of Anesthesia and Pharmaceutical Chemistry, University of California, San Francisco, CA, USA

\begin{abstract}
Inappropriate signalling through the EGFR and ErbB2/HER2 members of the epidermal growth factor family of receptor tyrosine kinases is well recognised as being causally linked to a variety of cancers. Consequently, monoclonal antibodies specific for these receptors have become increasingly important components of effective treatment strategies for cancer. Increasing evidence suggests that ErbB3 plays a critical role in cancer progression and resistance to therapy. We hypothesised that co-targeting the preferred ErbB2/ErbB3 heterodimer with a bispecific single-chain Fv (bs-scFv) antibody would promote increased targeting selectivity over antibodies specific for a single tumour-associated antigen (TAA). In addition, we hypothesised that targeting this important heterodimer could induce a therapeutic effect. Here, we describe the construction and evaluation of the A5-linker-ML3.9 bs-scFv (ALM), an anti-ErbB3/ErbB2 bs-scFv. The A5-linker-ML3.9 bs-scFv exhibits selective targeting of tumour cells in vitro and in vivo that co-express the two target antigens over tumour cells that express only one target antigen or normal cells that express low levels of both antigens. The A5-linker-ML3.9 bs-scFv also exhibits significantly greater in vivo targeting of ErbB2 ' + '/ErbB3' + ' tumours than derivative molecules that contain only one functional arm targeting ErbB2 or ErbB3. Binding of ALM to ErbB2' + '/ErbB3' +' cells mediates inhibition of tumour cell growth in vitro by effectively targeting the therapeutic anti-ErbB3 A5 scFv. This suggests both that ALM could provide the basis for an effective therapeutic agent and that engineered antibodies selected to co-target critical functional pairs of TAAs can enhance the targeting specificity and efficacy of antibody-based cancer therapeutics.

British Journal of Cancer (2008) 99, |4 I5- |425. doi:I0.1038/sj.bjc.6604700 www.bjcancer.com
\end{abstract}

Published online 7 October 2008

(c) 2008 Cancer Research UK

Keywords: engineered antibody; bispecific; ErbB

Although many treatment options exist for metastatic breast cancer, additional curative strategies are required. The development of antibodies that target critical signalling pathways implicated in cancer initiation and progression is one area of active research focused on this concern. The ErbB family (ErbB1/EGFR, ErbB2/HER2, ErbB3/HER3 and ErbB4/HER4) of receptor tyrosine kinases (RTKs) is known to drive both formation and progression of a number of commonly occurring cancers, including breast cancer, due to the normal role of these RTKs in regulating cell growth and survival (Yarden and Sliwkowski, 2001; Hynes and Lane, 2005). Therefore, these RTKs are important targets for the development of new antibody-based therapeutics. At present, the anti-ErbB2 monoclonal antibody (MAb) trastuzumab is the only antibody approved for use against metastatic breast cancer. Trastuzumab, most likely due to a multifaceted mechanism (for review, see Hynes and Lane, 2005) is efficacious against cancer that is driven by ERBB2 gene amplification

* Correspondence: Dr MK Robinson or Dr GP Adams, Department of Medical Oncology, Fox Chase Cancer Center, 333 Cottman Avenue, Philadelphia, PA 191।I, USA; E-mails: mk_robinson@ fccc.edu or gP_adams@fccc.edu

Revised 29 August 2008; accepted 8 September 2008; published online 7 October 2008
(Slamon et al, 2001). This subset of cancer is associated with poor patient outcome due to enhanced tumour aggressiveness and high risk of relapse (Slamon et al, 1989) but accounts for only $20-30 \%$ of the total patient population. Increased patient coverage is necessary. A second anti-ErbB2 MAb, pertuzumab, binds to an epitope in domain II of the extracellular domain (ECD) sterically inhibiting the binding pocket necessary for receptor dimerisation (Hynes and Lane, 2005). By preventing dimerisation, pertuzumab effectively blocks ligand-dependent proliferation of non-geneamplified breast and prostate cancer cells in culture (Agus et al, 2002). These results have led to the initiation of clinical trials in non-gene-amplified patient populations, although with limited success to date (Gordon et al, 2006; Walshe et al, 2006; Agus et al, 2007; de Bono et al, 2007).

In contrast to eliciting a therapeutic effect by directly altering signalling events, antibodies can be used to selectively deliver cytotoxic payloads to cancer cells (for review, see Adams and Weiner, 2005). However, tumour-associated antigens are often expressed at lower levels on normal tissues and are known to function as 'off-site' targets for therapeutic antibodies. For example, acneform rash associated with cetuximab-dependent inhibition of EGFR signalling in the skin is correlated with clinical responses in colorectal cancer patients (Cunningham et al, 2004). In some cases, targeting an antigen present in normal tissues can 
lead to significant toxicity or even death, particularly when a cytotoxic immunoconjugate is employed (Pai et al, 1991; Knox et al, 2000; Seidman et al, 2002). One possible mechanism to enhance the therapeutic efficacy of MAb-based treatment is to improve the targeting selectivity of these agents. Tumour targeting of small, engineered antibodies is greatly influenced by the functional affinity imparted through avid binding (Adams et al, 1993, 2006). We hypothesised that this contribution of functional affinity could be exploited, through the use of bispecific antibodies (bsAbs), to improve tumour uptake and targeting selectivity over normal tissue that expresses only one (or low levels of both) target antigen. Other groups have developed bsAb-based molecules that simultaneously target two tumour-associated antigens such as EGFR and insulin growth factor receptor (IGFR) (Lu et al, 2005) or carcinoembryonic antigen (CEA) and ErbB2 (Dorvillius et al, 2002). However, there has been little evidence that bsAb-based targeting strategies can be employed to enhance targeting specificity.

On the basis of multiple lines of evidence, we hypothesised that the ErbB2/ErbB3 heterodimer would be a valuable target for the development of a bsAb for the treatment of breast cancer. First, the ErbB2/ErbB3 heterodimer constitutes the most potent ErbB signalling pair when measured in cell culture assays (Yarden and Sliwkowski, 2001; Hynes and Lane, 2005). Second, expression of either ErbB2 or ErbB3 is associated with poor prognosis in breast cancer. Third, the receptors are frequently co-expressed in human breast cancer (Gasparini et al, 1994; Naidu et al, 1998; Witton et al, 2003); Naidu et al (1998), in a 220 patient study, showed that greater than $50 \%$ of all tumours expressed moderate to high levels of either ErbB2 or ErbB3, with their co-expression being higher than any other pair of ErbB family members. To that end, we developed an anti-ErbB2/ErbB3 bispecific single-chain Fv molecule. Here, we present both in vitro and in vivo evidence of its selective targeting of cells that co-express both target antigens. In addition, we demonstrate that the bispecific single chain-Fv (bs-scFv) has intrinsic anti-cancer activity when measured in vitro and that the anti-ErbB3 arm of the bs-scFv is responsible for mediating this activity.

\section{MATERIALS AND METHODS}

\section{Cell lines}

The BT-474 (ATCC no. HTB-20), SK-OV-3 (ATCC no. HTB-77), MDA-MB-468 (ATCC no. HTB-132), MCF10a (ATCC no. CRL10317) and B16-F0 (ATCC no. CRL-6233) cell lines were obtained from the American Type Culture Collection (ATCC). MDA-361/ DYT2 is a derivative of MDA-MB-361 (ATCC no. HTB-27) and was a kind gift from Dr D Yang (Georgetown University; Yang et al, 1998). All cells were maintained in DMEM supplemented with $10 \%$ fetal bovine serum (FBS). MVM2 cells are a derivative of B16-F0 murine melanoma cells transfected to express full-length human ErbB2 under control of the CMV promoter. The human cDNA of ErbB2 was obtained from pSVHER2 (gift from Dr T Eberlein; Yoshino et al, 1994) and subcloned into pLNCX as a $4.6 \mathrm{~Kb}$ HindIII fragment to create pLNCX-HER2. pLNCX-ERBB2 was transfected into B16-F0 cells through electroporation, and transfectants were selected in DMEM supplemented with $10 \%$ FBS and $1.8 \mathrm{mg} \mathrm{m}^{-1}$ G418. Clones were expanded and cell surface expression of ErbB2 was confirmed by flow cytometry with mouse anti-ErbB2 MAb 520C9 (gift from Dr D Ring, Chiron Corporation) and goat antimouse-FITC conjugated secondary antibody. The MVM2 clone was selected on the basis of its high level of expression by flow cytometry. Expression levels of ErbB2 and ErbB3 on each of the cell lines used in this study were measured by quantitative flow cytometry with the QuantiBrite System (Becton Dickinson) using the manufacturer's protocols. Anti-ErbB2 (Becton Dickinson, cat no. 340552) and anti-ErbB3 (R\&D, cat no. FAB3481P) conjugated to a $1: 1$ ratio with phycoerythrin $(\mathrm{PE})$ by the manufacturers were used for monitoring expression levels with the mean of three independent experiments reported in Table 1.

\section{Construction of bs-scFv}

The anti-ErbB3/anti-ErbB2 bs-scFv was created from the A5 antiErbB3 (Horak et al, 2005) and ML3.9 anti-ErbB2 (Schier et al, 1996) scFvs using a multistep cloning strategy. Briefly, sense $\left(5^{\prime}<\right.$ AATTCAGGTGCTGGTACTTCAGGTTCAGGTGCTTCAGGTG AAGGTTCAGGTTCAA $\left.>3^{\prime}\right)$ and anti-sense $\left(5^{\prime}<\right.$ AGCTTTGAACC TGAACCTTCACCTGATGCACCTGAACCTGAAGTACCAGCACCT $G>3^{\prime}$ ) oligos encoding a peptide linker sequence (NSGAGTSGSG ASGEGSGSKL) were hybridised and cloned into pET20b $(+)$ (Novagen) as an EcoRI/HindIII fragment to create pET20b-L. The anti-ErbB3 scFv was amplified from pSYN-A5 (Horak et al, 2005) by PCR with primers that encompassed the NcoI site at the 5 -end of the gene and incorporated an in-frame EcoRI site at the $3^{\prime}$-end of the gene. The fragment was subcloned into pET20b-L as an NcoI/EcoRI fragment to create pET20b-AL. The ML3.9 scFv was amplified from pSYN-ML3.9 (Schier et al, 1996) with primers that incorporated in-frame HindIII and XhoI sites at the $5^{\prime}$ - and $3^{\prime}$-ends of the gene, respectively, and was then subcloned into pET20b-AL as a HindIII/XhoI fragment to create pET20b-A5-linker-ML3.9 bs-scFv (ALM). The A5-linker-ML3.9 bs-scFv was then subcloned into pSYN as an NcoI/NotI fragment. This construct (pSYN-ALM) contains an XhoI site, 6XHIS tag and stop codon derived from the pET20b $(+)$ vector $5^{\prime}$ to the pSYN-encoded NotI site. To facilitate substitution of individual arms, the EcoRI and HindIII sites present in the polylinker of PSYN-ALM were destroyed by site-directed mutagenesis with the QuikChange Site-Directed Mutagenesis kit (Stratagene) using the manufacturer's protocols.

The 'dead' D3 scFv was isolated from a human phage-display library (Yuan et al, 2006) and binds to an epitope formed by the junction between a biotinylated peptide and streptavidin. Binding, as measured by surface plasmon resonance (SPR) on a BIAcore1000 (BIAcore, Piscataway, NJ, USA), requires the presence of both the peptide and SA; binding cannot be competed with either of the components alone. The $\mathrm{D} 3 \mathrm{scFv}$ was amplified by PCR with primers that incorporate either in-frame NcoI/EcoRI or HindIII/XhoI restriction sites and sublconed into PSYN-ALM to create PSYN-DLM and PSYN-ALD.

\section{Physical characterization of bs-scFvs}

Bispecific-scFvs were expressed in Escherichia coli and purified by sequential IMAC and size-exclusion chromatography essentially as described (Robinson et al, 2005). Binding of the A5 and the ALM bs-scFv to ErbB2 and ErbB3 ECDs was characterized by SPR using ErbB2 and ErbB3 ECDs (Horak et al, 2005) as target antigens and

Table I Expression levels of ErbB2 and ErbB3 on cell lines

\begin{tabular}{lcc}
\hline Cell line & ErbB2 & ErbB3 \\
\hline SK-OV-3 & $9.6 \times 10^{5}$ & $3.0 \times 10^{3}$ \\
BT-474 & $7.6 \times 10^{5}$ & $5.1 \times 10^{4}$ \\
MDA-36I/DYT2 & $2.9 \times 10^{5}$ & $2.2 \times 10^{4}$ \\
MDA-MB-468 & $<1 \times 10^{2}$ & $1.6 \times 10^{4}$ \\
MCFIOa & $3.5 \times 10^{4}$ & $5.0 \times 10^{3}$ \\
T-47D & $5.2 \times 10^{4}$ & $\mathrm{ND}$ \\
MDA-MB-23I & $2.8 \times 10^{4}$ & $\mathrm{ND}$ \\
MVM2 & $3.5 \times 10^{5}$ & $\mathrm{NA}$ \\
\hline
\end{tabular}

$\mathrm{NA}=$ not applicable, cell line is of murine origin and not expected to express human ErbB3; $N D=$ not tested. Expression levels were determined by quantitative flow cytometry on the basis of the assumption that each antibody bound to two receptors. 
methods described previously (Yuan et al, 2006). Extracellular domains were diluted to $10 \mu \mathrm{g} \mathrm{ml}^{-1}$ in $10 \mathrm{~mm}$ sodium acetate, $\mathrm{pH}$ 5.2 , and approximately $200 \mathrm{RU}$ of ECDs were immobilized onto CM5 sensor chips through NHS-ester chemistry. Kinetic constants for A5 were determined by passing serially diluted samples $(0 \mathrm{nM}$ to $2 \mu \mathrm{M})$ over flow cells at a flow rate of $40 \mu \mathrm{min}^{-1}$. Response against an ErbB2-coated flow cell was used as a negative control and subtracted from the response generated against the ErbB3 ECD to obtain the final sensorgrams. Data was evaluated using BIAEvaluation 3.2 software (BIAcore, Piscataway, NJ, USA) and fit using the 1:1 Langmuir binding model. Flow cells were regenerated by sequential $15 \mathrm{~s}$ pulses with $10 \mathrm{~mm}$ glycine, $\mathrm{pH} 2$, and $50 \mathrm{~mm}$ triethylamine, $\mathrm{pH} 10$, followed by equilibration with $\mathrm{PBS}$ running buffer.

Stability of ALM in human serum was assayed as follows. The A5-linker-ML3.9 bs-scFv was radioiodinated with Iodine-125 (Perkin Elmer, cat no. NEZ033H) using iodogen-coated glass tubes (Pierce, cat no. 28601) essentially as described (Fraker and Speck, 1978). Briefly, $300-500 \mu \mathrm{g}$ of a bs-scFv was labelled with $0.75-1.35 \mathrm{mCi}$ of $\mathrm{Na}^{125} \mathrm{I}\left(17 \mathrm{Ci} \mathrm{mg}^{-1}, 350 \mathrm{mCi} \mathrm{ml}^{-1}\right)$ containing $10 \mu \mathrm{M}$ carrier NaI. Labelled protein was purified from nonincorporated ${ }^{125}$ I by size-exclusion chromatography over a PD10 column (Amersham Pharmacia) and percentage of incorporation was determined by ITLC (Biodex). This protocol resulted in radioiodination of the bs-scFvs at efficiencies between 14 and $42 \%$ and produced product with a specific activity of $0.5-1.3 \mu \mathrm{Ci} \mu \mathrm{g}^{-1}$ that was $>95 \%$ pure by ITLC. Immunoreactivity of the radiolabelled bs-scFvs ranged from being 50 to $67 \%$ active as judged by live-cell binding assays with SK-OV-3 cells as described previously (Adams et al, 1993). Radioiodinated ALM (200 $\mathrm{ng}^{-1} \mathrm{l}^{-1}$ ) was diluted 10-fold in human serum (final volume $100 \mu \mathrm{l}$ ) and incubated at $37^{\circ} \mathrm{C}$ over a time course of $72 \mathrm{~h}$. At each time point, a $10 \mu \mathrm{l}$ aliquot was removed and retention of activity, as compared with $T=0$, was determined by live-cell binding. The FDAapproved anti-ErbB2 MAb trastuzumab was radioiodinated and assayed side by side as a positive control.

\section{In vitro selectivity}

MDA-MB-468 cells (ErbB2-/ErbB3 + ) were stained with $20 \mu \mathrm{M}$ Cell Tracker Blue CMAC (Molecular Probes, cat no. C-2110), MVM2 (ErbB2 + /ErbB3-) and MCF10a (ErbB2 + /ErbB3 + ) cells were stained with $10 \mu \mathrm{m}$ Cell Tracker Orange CMTMR (Molecular Probes, no. C-2927) and BT-474 cells (ErbB2 +/ErbB3 + ) were left unstained, as appropriate for each individual experiment. Cells were plated in six-well plates ( 300000 cells per well) and allowed to adhere overnight. Once adhered, cells were incubated in serumfree DMEM containing appropriate Cell Tracker dyes for $45 \mathrm{~min}$, wells were rinsed with Dulbecco's PBS (Invitrogen, cat. no. 14287072) to remove excess dye and cells were allowed to recover in DMEM containing 10\% FBS for $30 \mathrm{~min}$. Following recovery, cells were trypsinized and counted. To determine the effect of bivalent vs monovalent targeting, cells were mixed in equal ratios, incubated with ALM at concentrations of $1 \mu \mathrm{M}, 0.1 \mu \mathrm{M}, 10 \mathrm{nM}$, $1 \mathrm{~nm}$ or $100 \mathrm{pm}$ for $30 \mathrm{~min}$ at $4^{\circ} \mathrm{C}$, washed with PBS and bound ALM was detected through its 6XHis tag with an anti-PentaHis-Alexa Fluor $488 \mathrm{MAb}$ (Qiagen, cat. no. 35310). The samples were subjected to flow cytometric analysis using either a FACS-LSIIR equipped with two lasers or a FACS-VantageSE/DiVa machine (Becton Dickinson) equipped with three lasers, one UV-capable, as necessary. The forward $v s$ side-scatter parameters were similar for all the cell lines allowing analysis as a single population. The Blue cell tracker dye was detected at the Cascade blue channel and the Orange Cell tracker dye at the PE channel. Three-color flow cytometry data were acquired using CELLQuest software (Becton Dickinson) and then analysed using the FlowJo software package (Tree Star Inc.). Data are representative of three independent experiments of $9 \times 10^{5}$ cells per sample with $\geqslant 50000$ events collected. To determine the effect of low-level expression of both ErbB2 and ErbB3 on ALM targeting, an increasing number of MCF10a cells were mixed with $2 \times 10^{5}$ BT-474 cells at ratios of $1: 1$ to $18: 1$, incubated with ALM $(100 \mathrm{nM})$ and analysed by flow cytometry $\left(1 \times 10^{5}\right.$ events were collected $)$ as described above.

\section{Biodistribution}

Male CB.17 ICR scid mice, 6-8 weeks of age, were obtained from the Fox Chase Cancer Center Laboratory Animal Facility, and cells were implanted as follows. SK-OV-3 $\left(3.0 \times 10^{6}\right)$, MDA-MB-468 $\left(6.0 \times 10^{6}\right)$ or MVM-2 $\left(3 \times 10^{6}\right)$ were implanted subcutaneously into the inguinal region of the mice. BT- $474\left(3.0 \times 10^{6}\right)$ cells were implanted following subcutaneous implantation of $17-\beta$-estradiol pellets (Innovative Research of America, cat. no. SE-121). At 3-7 weeks post-implantation, depending on cell line, tumours were $100-300 \mathrm{~mm}^{3}$ in size. Lugol's solution (Sigma, cat. no. L6146) was added to the drinking water at a final concentration of $0.2 \%$ to block thyroid accumulation of radioiodine, and biodistribution studies were initiated approximately 5 days later. Bispecific single chain FVS were radioiodinated as described above, and ${ }^{125}$ I-bs-scFvs ( $\sim 20 \mu \mathrm{g}$ per mouse) were administered to cohorts of mice $(n \geqslant 5$ per cohort) through tail-vein injection, mice were euthanized at indicated times post-injection and dissected, and major organs were weighed and counted in a $\gamma$ well counter (Cobra Quantum, Packard Instruments) with a window of $15-75 \mathrm{keV}$. The retention in tumour and non-target tissues was expressed as a percentage of the injected dose localised per gram of tissue (\% ID per g) as determined from decay-corrected counts as described previously (Adams et al, 1993). The mean and standard error of the mean (s.e.m.) values reported are typical results obtained from at least two replicates of each experimental condition.

\section{In vitro efficacy}

MDA-361/DYT2 and BT-474 cells $\left(1.5 \times 10^{5}\right)$ were plated in sixwell plates (Nunclon, cat. no. 140685) and allowed to adhere overnight. Cells were left untreated, treated with increasing concentrations of ALM for 4 days or treated with $4 \mu \mathrm{M}$ doxorubicin (Pharmacia \& Upjohn) for $24 \mathrm{~h}$. Cells were then analysed for apoptosis by flow cytometry with the Guava Nexin kit using the manufacturers protocol. Samples were analysed using a Guava Technologies Personal cytometer with Annexin V-PE and the membrane impermeant dye 7-Amino-actinomycin D (7-AAD) as markers for early and late apoptosis, respectively. Cell cycle compartment analysis was performed by flow cytometry. Cells $\left(1 \times 10^{6}\right)$ were fixed with ice-cold $70 \%$ ethanol, treated with RNaseA $\left(1 \mathrm{mg} \mathrm{ml}^{-1}\right)$ for $30 \mathrm{~min}$ and then stained with propidium iodine at a concentration of $50 \mathrm{mg} \mathrm{ml}^{-1}$. Cells were analysed by flow cytometry on a Becton Dickinson FACscan flow cytometer with CellQuest DNA software. Inhibition of colony formation was performed as follows. MDA-361/DYT2 and BT-474 were seeded into six-well plates (6000 cells per well) in a total volume of $2 \mathrm{ml}$ media and allowed to adhere overnight. In triplicate, media containing the appropriate antibodies (as described in figure legends) were added to cells and then refreshed every 5 days. After 2 weeks, colonies were fixed in $70 \%$ ethanol and then stained with $0.25 \%$ methylene blue and $30 \%$ ethanol, and colonies were counted with an automatic colony counter (MiniCount, IPI Inc.) with a cutoff of $0.35 \mathrm{~mm}$. Data presented for all in vitro analyses represent typical results from at least three independent experiments. Pertuzumab (hu2C4, Genentech) at a concentration of $300 \mathrm{~nm}$ was used as a positive control for these experiments.

\section{Statistical analysis}

Average and s.e.m. were calculated for all organs and tumours in the biodistribution experiments. Averages and standard deviations 
were calculated for apoptosis and colony-forming assays. Unpaired $t$-tests were used to determine the statistical significance by using the online calculator available at the GraphPad Software website (http://www.graphpad.com/quickcalcs/ContMenu.cfm). $P$-values $\leqslant 0.05$ were considered to be statistically significant.

\section{RESULTS}

\section{Physical characteristics of ALM}

To test the hypothesis that bispecific targeting will increase tumour-targeting selectivity of antibody-based agents, we took advantage of two previously identified scFv, the anti-ErbB2 ML3.9 scFv (Schier et al, 1996) and the anti-ErbB3 A5 scFv (Horak et al, 2005). The ML3.9 SeFV binds to the ErbB2 ECD with a $K_{\mathrm{D}}$ of $1.1 \times 10^{-9} \mathrm{M}$ (Schier et al, 1996) and A5 scFv binds to ErbB3 ECD with a $K_{\mathrm{D}}$ of $1.6 \times 10^{-7} \mathrm{M}$ (Figure 1 ) as measured by SPR. To create $\mathrm{ALM}$, we fused the genes for the two $\mathrm{scFv}$ with an oligonucleotide linker that encodes for a 20 amino acid peptide (Figure 2A). The A5-linker-ML3.9 bs-scFv is soluble when expressed and secreted into the periplasmic space of $E$. coli. Figure $2 \mathrm{~B}$ depicts a representative chromatograph of ALM over a Superdex 75 column following IMAC purification and demonstrating that the majority ( $87 \%$ in this case) of the protein, as measured by UV absorption, is located in the monomeric peak. Fractions containing the monomeric protein were used for all subsequent analysis. Storage at $4{ }^{\circ} \mathrm{C}$ for at least 4 weeks does not alter the chromatographic profile of
$\mathrm{ALM}$, and protein can be stored at $-80^{\circ} \mathrm{C}$ without an effect on activity as judged by live-cell binding (data not shown). Fusing the scFvs into the 'ALM' bs-scFv format did not dramatically alter the antigen-binding kinetics of either scFv. In addition, ALM can bind simultaneously to both ErbB2 and ErbB3 as measured by SPR (data not shown). Although somewhat artificial as compared with binding both antigens on the cell surface, these results indicate that both arms of the bs-scFv were independently active. Together, these data supported further in vitro and in vivo evaluation of the potential for bivalent binding to enhance targeting selectivity. Further evaluation was also supported by stability of the bs-scFv in human serum. The A5-linker-ML3.9 bs-scFv retained 92 and $89 \%$ of its ability to bind to ErbB2' +'/ErbB3' + ' SK-OV-3 cells after 48 and $72 \mathrm{~h}$, respectively, when incubated at $37^{\circ} \mathrm{C}$ in human serum - a time frame compatible with the clearance properties of the antibody. By comparison, trastuzumab retained $\sim 100 \%$ of its activity at $48 \mathrm{~h}$. Consistent with the known biology of ErbB2 and ErbB3, ALM is internalised upon binding to ErbB2' +' 'ErbB3' + ' cells. Within $15 \mathrm{~min}, 23 \pm 0.85 \%$ of ALM was internalised, and by $120 \mathrm{~min}, 36 \pm 0.24 \%$ of ALM was internalised with an additional $47 \pm 0.16 \%$ stably bound to the cell surface.

\section{The A5-linker-ML3.9 bs-scFv selectively targets ErbB2' +'/ ErbB3'+' cells in vitro}

The ability of bivalent association of ALM to promote selective tumour $v s$ normal tissue uptake was addressed using in vitro, flow

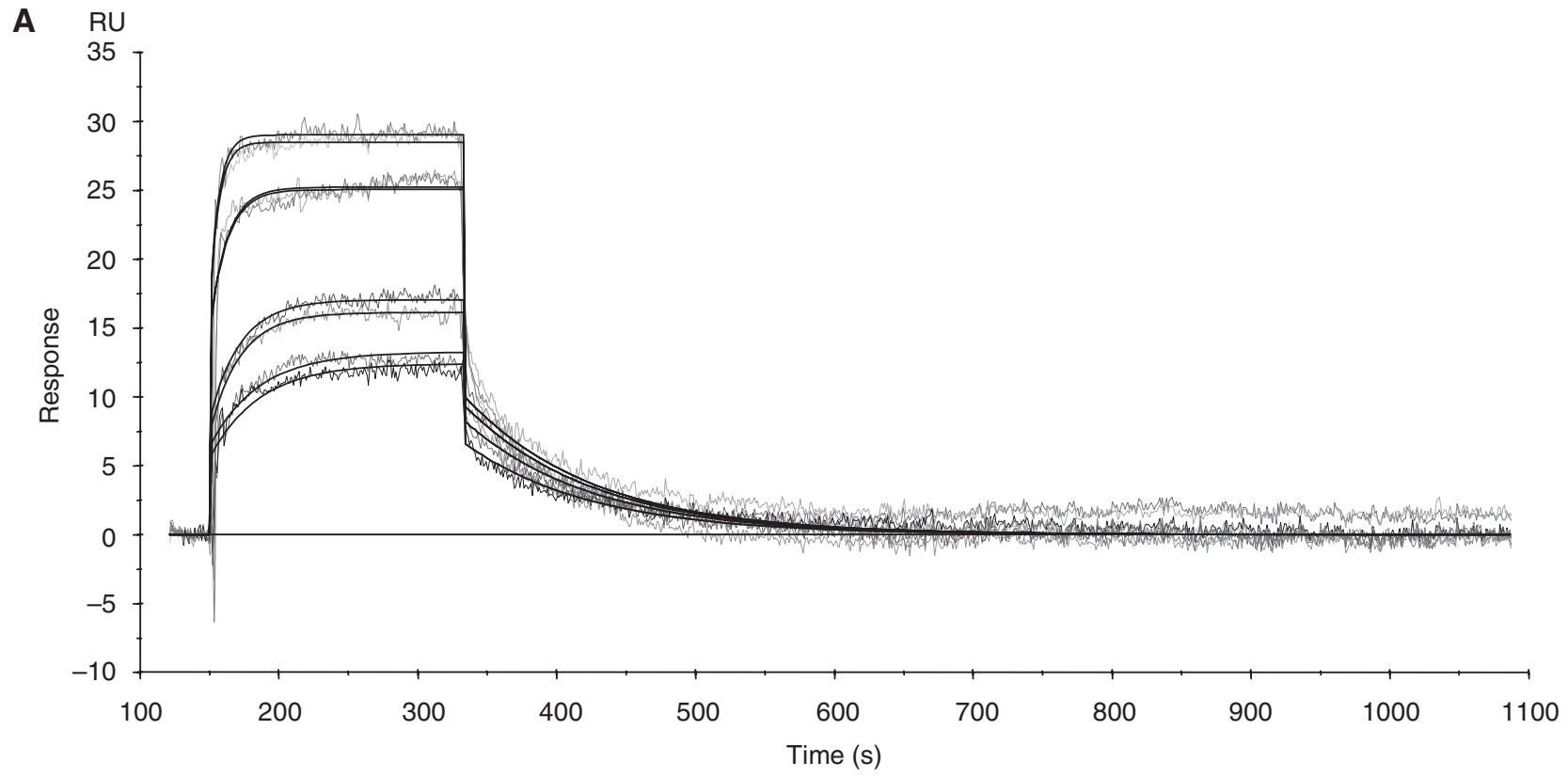

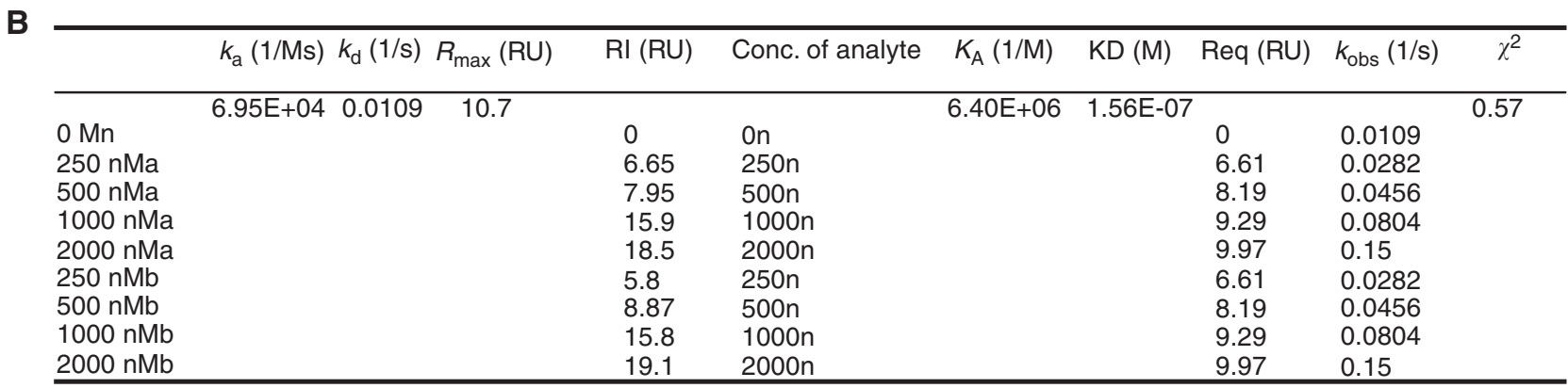

Figure I Affinity and binding kinetics of the anti-ErbB3 A5 scFv. $k_{\text {on }}$ and $k_{\text {off }}$ rates were determined by surface plasmon resonance and used to determine the binding affinity $\left(K_{D}\right)$ of the A5 scFv. (A) Sensorgram fit to I : I Langmuir binding model. (B) Analysis of data. 
A

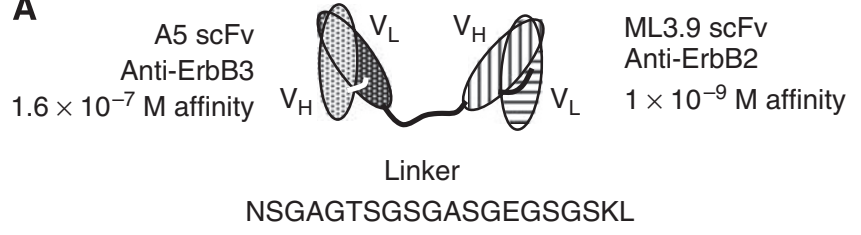

B

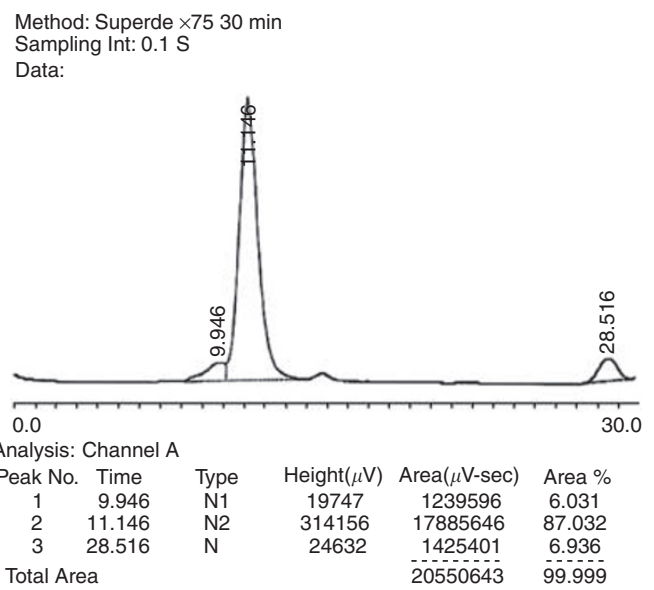

Figure 2 The anti-ErbB2/ErbB3 bs-scFv ALM. (A) Cartoon of ALM depicting scFv orientation, linker sequence and kinetic constants of ALM for each target antigen. (B) UV adsorption spectrum chromatograph of ALM over Superdex 75 size-exclusion column.

Table 2 ALM selectively targets ErbB2/ErbB3 positive cells in vitro

\begin{tabular}{lccl}
\hline & \multicolumn{3}{c}{ \% Positive cells $^{\mathbf{a}}$} \\
\cline { 2 - 4 } ALM & $\begin{array}{c}\text { BT-474 } \\
\text { (ErbB2/ErbB3) }\end{array}$ & $\begin{array}{c}\text { MVM2 } \\
\text { (ErbB2/-) }\end{array}$ & $\begin{array}{l}\text { MDA-MB-468 } \\
\text { (-/ErbB3) }\end{array}$ \\
\hline I $\mu \mathrm{M}$ & 99.6 & 99.2 & $\mathrm{ND}$ \\
$100 \mathrm{nM}$ & 98.6 & 95.5 & $\mathrm{ND}$ \\
$10 \mathrm{nM}$ & 78.2 & 32.4 & $\mathrm{ND}$ \\
I nM & 23.5 & 3.6 & $\mathrm{ND}$ \\
$100 \mathrm{pM}$ & 17.0 & 1.74 & $\mathrm{ND}$ \\
Anti-6xHis MAb alone & 1.26 & 1.24 & $\mathrm{NA}$ \\
\hline
\end{tabular}

$\mathrm{NA}=$ not applicable: $\mathrm{ND}=$ not detectable. ${ }^{\mathrm{a}}$ Numbers represent the percentage of each cell type bound by increasing concentrations of ALM after the three lines were stained with CellTracker dyes, mixed together in equal numbers, incubated with ALM and subjected to flow cytometry.

cytometry-based assays. First, MVM2 cells and MDA-MB-468 were used to approximate normal tissues that express only ErbB2 or only ErbB3, respectively, and BT-474 cells represented ErbB2' + ' ErbB3'+'-positive tumours. The A5-linker-ML3.9 bs-scFv failed to discriminate between BT-474 (ErbB2' +' $\left./ \mathrm{ErbB}^{\prime}{ }^{\prime}+{ }^{\prime}\right)$ and MVM2 (ErbB2'+'/ErbB3'-') cell lines at concentrations $\geqslant 100 \mathrm{nM}$ (Table 2), consistent with high concentrations of ALM favouring monovalent association with cell lines that overexpress ErbB2. At $10 \mathrm{nM}$, a concentration approaching the $K_{\mathrm{D}}$ of the ML3.9 scFv for ErbB2, a 3-fold drop in association with MVM2 (ErbB2'+'/ ErbB3'-') cells was seen with only a corresponding 1.2-fold drop in association with the BT-474 cells. This resulted in 2.4 times as many BT-474 (ErbB2' +'/ErbB3'+') cells bound by ALM as compared with MVM2 (ErbB2' +'/ErbB3'-') cells. This difference in binding was more pronounced at lower concentrations of ALM, where 6.5 and 9.7 times as many BT-474 cells, as compared with MVM2 (ErbB2' + '/ErbB3'-') cells, were bound by ALM at $1 \mathrm{nM}$ and $100 \mathrm{pm}$, respectively. Consistent with the low affinity of A5 for
ErbB3, binding to the MDA-MB-468 (ErbB2‘-'/ErbB3'+') cell line was not detected at concentrations as high as $1 \mu \mathrm{M}$.

To model the effects of ErbB2' + '/ErbB3' + ' normal tissue on ALM targeting, we used fluorescently labelled MCF10a normal breast epithelial cells mixed with unlabelled BT-474 tumour cells. MCF10a cells express significantly lower levels of both target antigens than BT-474 cells (Table 1). MCF10a (ErbB2' \pm '/ ErbB3' \pm ') and BT-474 (ErbB2' + '/ErbB3' + ') cells were readily distinguishable by flow cytometry when mixed at both $1: 1$ and 18:1 ratios of MCF10a:BT-474 (Figure 3). The A5-linker-ML3.9 bs-scFv (100 nM) specifically bound to BT-474 cells as compared with the normal MCF10a cells when added to a 1:1 mixture of cells. The A5-linker-ML3.9 bs-scFv was detected in $68.5 \%$ of the BT-474 cells, whereas MCF10a (ErbB2' \pm '/ErbB3' \pm ') cells failed to exhibit significant ALM binding. However, ErbB2' +'/ErbB3'+' normal cells are predicted to be in vast excess compared with tumour cells in vivo. To begin to mimic this situation, we incubated ALM with BT-474 cells that were mixed with increasing numbers of MCF10a (ErbB2' \pm '/ErbB3' \pm ') cells. At MCF10a:BT-474 ratios as high as 18:1 (maximum ratio tested due to constraints of the assay), the presence of 'normal tissue' had no significant impact on the ability of ALM to specifically bind to tumour cells. The A5-linker-ML3.9 bs-scFv was detected on $62 \%$ of BT-474 (ErbB2' +'/ErbB3'+') cells present in the assay without significantly binding to MCF10a (ErbB2' \pm '/ErbB3' \pm ') cells despite the 18-fold higher number of these cells (Figure 3C). This concentration of ALM was capable of binding monovalently to MVM2 cells in such as way as to prevent selective binding between BT-474 (ErbB2' +'/ErbB3' $+{ }^{\prime}$ ') and MVM2 (ErbB2‘ +'/ErbB3'-') cells (Table 2). MVM2 (ErbB2‘+'/ ErbB3'-') cells express $3 \times 10^{5}$ copies of ErbB2 on the cell surface. This level of expression is equivalent to, or higher than, many ErbB2-positive breast cancer cells lines, such as MDA-361/DYT2 $\left(3.7 \times 10^{5}\right)$, T-47D $\left(5.2 \times 10^{4}\right)$ and MDA-MB-231 $\left(2.8 \times 10^{4}\right)$ when measured in vitro by quantitative flow cytometry (Table 1 and Tang et al, 2007). Together, these data show that ALM is capable of selectively targeting tumour cells that express high concentrations of both target antigens over cells that express high levels of only one target antigen or low levels of both target antigens. In the latter case, this occurred even when the ErbB2' +'/ErbB3'+' tumour cells represented a minority of the total cells in the assay. This suggests that ALM could exhibit selective tumour-targeting advantages in the clinical setting where both target antigens are present at lower concentrations in a number of normal tissues.

\section{The A5-linker-ML3.9 bs-scFv specifically targets ErbB2' + 'ErbB3' +' tumours in vivo}

Consistent with the proposed hypothesis that bivalent binding will increase tumour retention, optimal targeting of ALM in vivo requires expression of both ErbB2 and ErbB3 on the tumour cell surface (Figure 4A). Radioiodinated ALM $\left({ }^{125} \mathrm{I}\right.$-ALM) accumulated to similar levels $(P=0.59)$ in two different ErbB2 ' + '/ErbB3' + ' tumour xenografts; ${ }^{125} \mathrm{I}-\mathrm{ALM}$ accumulated in BT-474 and SK-OV-3 tumour xenografts at $2.89 \pm 0.2$ and $3.07 \pm 0.27 \%$ injected dose per gram of tissue (\% ID per g), respectively, by $24 \mathrm{~h}$ post-injection. These levels are statistically greater than those seen in blood $(P<0.001)$ or any other tissues analysed $(P<0.001)$ and are consistent with the rapid targeting selectivity exhibited by antiErbB2 dimeric scFvs against SK-OV-3 xenografts (Adams et al, 2006). Both SK-OV-3 and BT-474 cells express low levels of ErbB3, as compared with ErbB2 (Table 1). However, SK-OV-3 cells express levels essentially equal to that of the normal MCF10a breast cell line, and 10-fold lower than BT-474 cells. This difference in ErbB3 expression strongly suggests that effective tumour targeting with bs-scFvs may not require overexpression of both target antigens relative to normal tissue. Rather, monovalent association with an overexpressed antigen may be used to drive initial targeting, with tumour retention being enhanced by avid 


\section{A 251858.fcs}
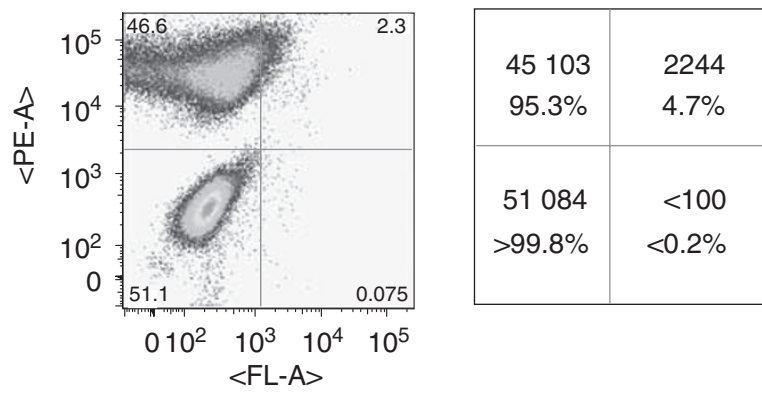

MCF10a

$1: 1$ ratio

$-\mathrm{ALM}$

BT-474

B 251860.fcs

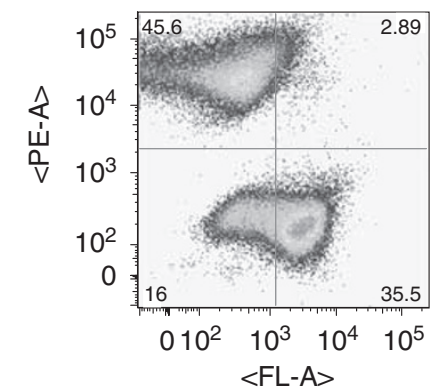

\begin{tabular}{|c|c|}
\hline 44437 & 2676 \\
$94.3 \%$ & $5.7 \%$ \\
\hline 16225 & 35256 \\
$31.5 \%$ & $68.5 \%$ \\
\hline
\end{tabular}

MCF10a

$1: 1$ ratio

+ ALM

C 251866.fcs

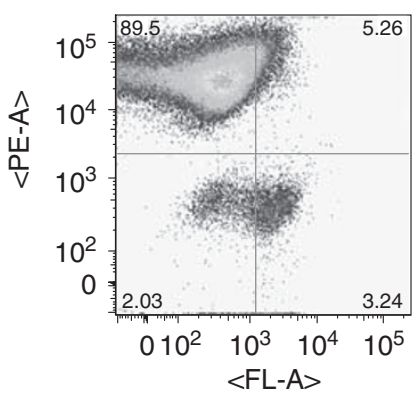

\begin{tabular}{|c|c|}
\hline 89247 & 5133 \\
$94.6 \%$ & $5.4 \%$ \\
\hline 1888 & 3075 \\
$38 \%$ & $62 \%$ \\
\hline
\end{tabular}

MCF10a

$18: 1$ ratio

+ ALM

BT-474

Figure 3 The A5-linker-ML3.9 bs-scFv selectively binds BT-474 tumour cells in vitro. Non-labelled BT-474 (ErbB2' + '/ErbB3' + ') breast tumour cells were mixed with either an equal $(\mathbf{A}$ and $\mathbf{B}$ ) or I8-fold excess (C) of fluorescently labelled MCFIOa (ErbB2 “ \pm '/ErbB3' \pm ') normal breast epithelial cells. Cell mixtures were then incubated with buffer $(\mathbf{A})$ or $100 \mathrm{nM}$ ALM (B and $\mathbf{C}$ ) and binding of ALM to each cell population was determined by flow cytometry with an anti-6XHis tag secondary antibody. MCFI Oa cells were sorted to the upper quadrants and the non-labelled BT-474 cells were sorted to the lower quadrants. Cells bound by the secondary antibody sorted to the respective right hand quadrants. Images on the left depict the raw flow cytometry data. Values on the right represent the absolute number and overall percentage of each cell type in the respective quadrants.

binding to the second antigen. Consistent with such a model, expression of both antigens, and therefore the potential for divalent binding, is necessary for optimal targeting of ALM. Despite the fact that ALM was retained in the ErbB2' +'/ErbB3'-' MVM2 tumours at statistically greater levels than seen in blood $(0.98 \pm 0.09$ vs $0.28 \pm 0.04 \% \mathrm{ID} / \mathrm{g} ; P<0.001)$, the levels of targeting were significantly lower than those seen in either the BT-474 or SK-OV-3 xenograft models $(P<0.001)$. Despite the expression of ErbB3 on the ErbB2'-'/ErbB3' +' MDA-MB-468 tumour model, ${ }^{125}$ I-ALM failed to accumulate to levels above that seen in blood $(0.29 \pm 0.07$ vs $0.29 \pm 0.03 \%$ ID per g; $P=0.55)$. The inability to target MDA-MB-468 tumours is consistent with the results of Adams et al (1998), which demonstrated that effective targeting and retention of anti-ErbB2 scFv antibodies to SK-OV-3 tumours, a tumour line that expresses $1 \times 10^{6}$ copies of ErbB2 per cell, require a threshold affinity of $1 \times 10^{-8} \mathrm{M}$. The low affinity of the A5 scFv, coupled with the relatively low level of ErbB3 expression (Table 1), suggests that targeting of ALM to ErbB2'-'/ErbB3'+' tissues would be minimal.

Undoubtedly, ErbB2 levels play a significant role in ALM targeting and may explain, at least in part, the lower level of targeting exhibited against MVM2 tumours, as compared with either SK-OV-3 or BT-474 tumours. To control for effects of antigen expression on overall targeting, we constructed bs-scFvs in which either the A5 scFv or the ML3.9 scFv were replaced with a 'dead' (D) scFv specific for a non-natural epitope. Targeting of these bs-scFvs was then analysed in a single SK-OV-3 (ErbB2'+'/ ErbB3' +') xenograft model. Targeting of ${ }^{125} \mathrm{I}$-DLM through the anti-ErbB2 ML3.9 scFv resulted in $1.55 \pm 0.28 \%$ ID per $g$ at $24 \mathrm{~h}$ post-injection (Figure 4B), significantly more uptake than seen in any non-target tissue $(P<0.001)$ but lower than that seen with ALM $(P<0.002)$. This level of targeting is similar to that displayed by the isolated ML3.9 scFv (Adams et al, 1998), consistent with monovalent targeting by DLM. These data again support the requirement for bivalent association of the bs-scFv with the cell surface to promote optimal targeting. The A5-linker-ML3.9 bs-scFv targeting of MVM2 (ErbB2'+'/ErbB3'-') xenografts and DLM targeting of SK-OV-3 (ErbB2' + '/ErbB3' +') xenografts, both driven solely by ErbB2 expression, showed similar levels of uptake $(P=0.089)$, although the trend favored DLM. This trend may again reflect the greater level of ErbB2 expression on the SK-OV-3 $\left(\mathrm{ErbB}^{\prime}+{ }^{\prime} / \mathrm{ErbB}^{\prime}+\right.$ ') cell line. Analogous to the lack of ALM 

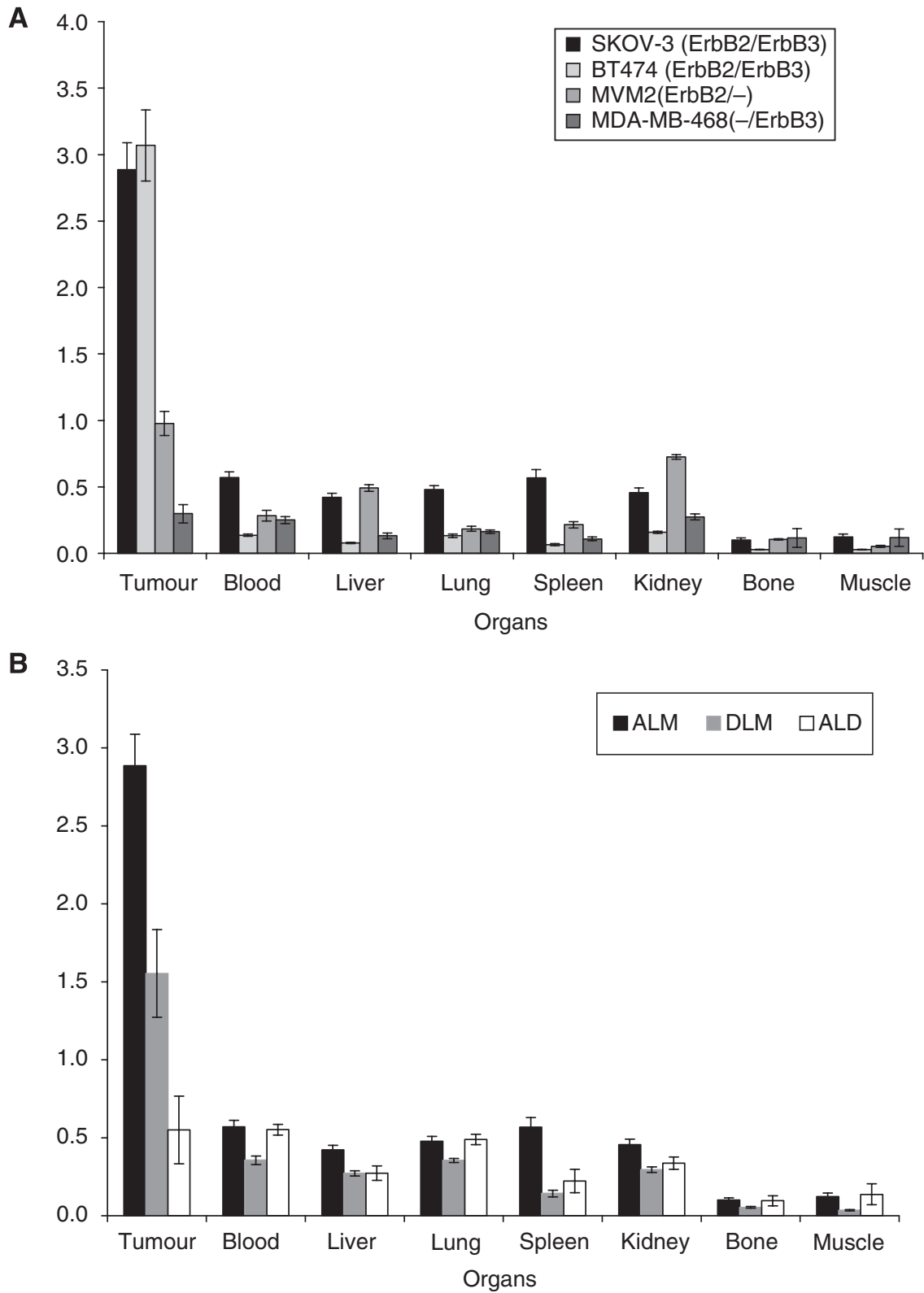

Figure 4 Bispecific binding is required for optimal tumour targeting of the ALM bs-scFv in vivo. The biodistributions of radioiodinated ALM, ALD and DLM bs-scFv were analysed $24 \mathrm{~h}$ post-injection into xenograft-bearing SCID mice ( $n=5$ per cohort). (A) Co-expression of ErbB2 and ErbB3 by the targeted tumour is required for optimal targeting of ALM in vivo. ${ }^{125}$ I-ALM targeted ErbB2 + /ErbB3 + tumour xenografts to $\geqslant 3$-fold higher levels than xenografts that express only one of the target antigens. (B) Radioiodinated ALM ( ${ }^{125}$ I-ALM), which is capable of bivalent association with the surface of Sk-OV-3 tumour cells, exhibited increased targeting as compared with ALD and DLM that targeted the tumours monovalently. Error bars represent the standard error of the mean (s.e.m.).

targeting seen against MDA-MB-468 (ErbB2'-'/ErbB3' + ') xenografts, ${ }^{125} \mathrm{I}-\mathrm{ALD}$, which has a functional anti-ErbB3 arm but no ability to bind to ErbB2, only accumulated to $0.55 \pm 0.16 \%$ ID per $g$ in SK-OV-3 (ErbB2' +'/ErbB3' +') tumours, a level that did not differ from that seen in blood $(P=0.78$, Figure $4 \mathrm{~B})$. This is again consistent with the threshold affinity required for effective in vivo targeting described by Adams et al (1998). The overall variations in non-target tissue uptake displayed by these bs-scFvs (Figure 4) may be explained, at least in part, by the process of internalization/ degradation and release of free iodine; all three constructs displayed the highest degree of variation (s.e.m. $=19-43 \%$ of total uptake) in stomach uptake, a tissue that expresses the $\mathrm{Na} / \mathrm{I}$ symporter.
The A5-linker-ML3.9 bs-scFv displays intrinsic anti-tumour cell activity

We hypothesised that targeting the ErbB2/ErbB3 heterodimer with ALM would have the potential to disrupt downstream signalling events. Consistent with this hypothesis, treatment of the ErbB2' +'/ErbB3'+' BT-474 and MDA-361/DYT2 cells with $250 \mathrm{nM}$ ALM induced apoptosis to a level of $\sim 20 \%$ as measured by flow cytometry with Annexin $\mathrm{V}$ and 7-AAD, as markers for early and late apoptosis, respectively (data not shown). Although the level of apoptosis is modest compared with the $>95 \%$ seen in doxorubicin-treated $(4 \mu \mathrm{M})$ controls, it is greater than the level seen in non-treated cells and cells treated with an irrelevant control 
scFv $(P<0.001)$. The low level of apoptosis is similar to that seen with trastuzumab in certain model systems (Pegram et al, 1999). More dramatically, ALM treatment inhibits growth of BT-474 and MDA-361/DYT2 cell lines in standard clonogenicity assays. Chronic treatment of BT-474 and MDA-361/DYT2 cells with $\geqslant 50 \mathrm{nM}$ ALM significantly reduced $(P<0.001)$ the ability of the cells to form colonies in a dose-dependent manner as compared with vehicle-treated cells (Figure 5A). Treatment with the clinically relevant MAb pertuzumab $(300 \mathrm{nM})$ inhibited the growth of both cell lines to similar levels as seen with $50 \mathrm{nM}$ ALM (data not shown). When taken together, these data suggest that ALM is eliciting a cytostatic, rather than cytotoxic, effect on the tumour cells. Consistent with this interpretation, ALM (250 nM) treatment increased the percentage of MDA-361/DYT2 cells in the G1 compartment of the cell cycle, as compared to cells treated with either rituximab or vehicle alone (Table 3). As predicted by published literature (Lewis et al, 1993; Yakes et al, 2002), MDA361/DYT2 cells were unresponsive to trastuzumab treatment in this assay (Table 3 ).

Interestingly, the therapeutic activity of ALM is almost entirely because of the anti-ErbB3 A5 arm of the bs-scFv. Chronic treatment of both BT-474 (Figure 5B) and MDA-361/DYT2 (Figure 5C) cells with A5 scFv significantly inhibited the growth of the cells in a dose-dependent manner. Although treatment with ML3.9 produced a modest, although statistically significant, dosedependent growth inhibition, the combination of A5 and ML3.9 scFv inhibited the growth of both cell lines to the same extent as A5 alone at all dose levels tested.

\section{DISCUSSION}

Classically, bsAbs have been developed to recognise both a tumour-associated antigen and a 'trigger antigen' present on the surface of an immune effector cell (Adams and Weiner, 2005) with the aim of redirecting the cytotoxic potential of effector cells against a patient's tumour (Weiner et al, 1993; Keler et al, 1997). Efforts to create such molecules have encompasssed full-length IgG (Weiner et al, 1993), chemically fused Fab' fragments (Shalaby et al, 1992; Keler et al, 1997) and, more recently, small engineered antibody fragments such as the scFv-based molecules (Shahied et al, 2004; Molhoj et al, 2007). Preclinical evaluation of these classes of molecules have demonstrated that bsAbs are capable of eliciting effector function against HER2-expressing cell lines in vitro and in animal models. In the case of the anti-HER2/ Fc $\gamma$ RIII 2B1 bsAb (Weiner et al, 1993) and the anti-HER2/Fc $\gamma$ RI MDX-H210 bs-Fab, the efficacy in animal models resulted in phase I clinical trials (Valone et al, 1995; Weiner et al, 1995).

Unlike the bsAbs mentioned above, the ALM bs-scFv antibody that we describe here binds two distinct tumour-associated antigens. We hypothesised that the effect of avid binding on the targeting of small engineered antibodies, as described by Adams et al (2006), could be exploited to increase targeting selectivity. Viewed in this context, our data suggest that bispecific binding of ALM is in fact a major component driving selective targeting of ALM. In particular, this hypothesis is supported by the in vitro targeting experiments showing that ALM is capable of selectively binding ErbB2 ${ }^{\prime}+' /$ ErbB3 $^{\prime}+$ ' tumour cells when present in a milieu of cells that express either elevated levels of one or normal
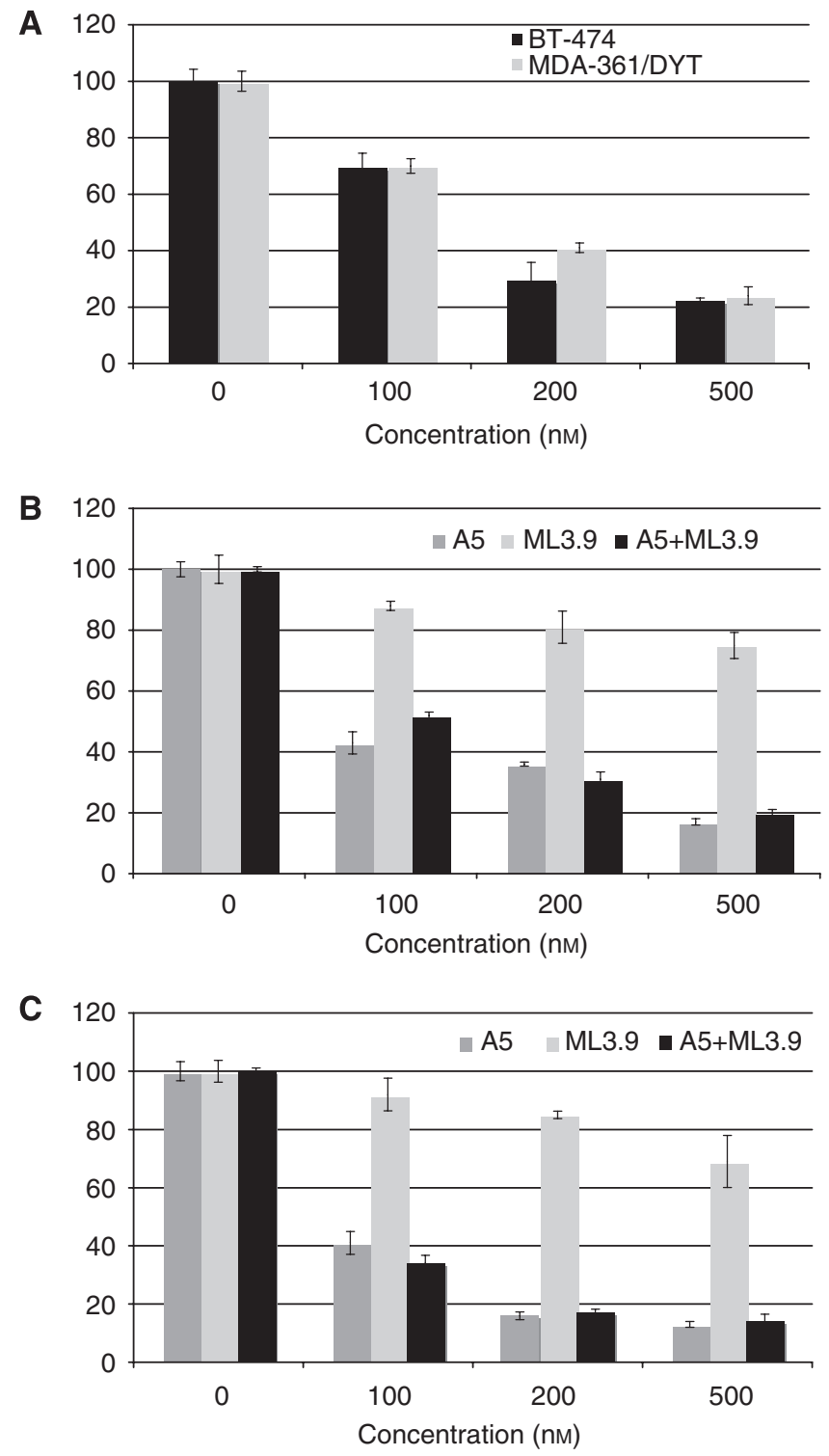

Figure 5 The A5-linker-ML3.9 bs-scFv has intrinsic anti-tumour cell activity. (A) Treatment of BT-474 and MDA-36I/DYT2 cells with ALM inhibits colony formation in clonogenicity assays. Treatment of (B) BT-474 or (C) MDA-36 I/DYT2 cells with A5 scFv, ML3.9 scFv or the combination of both indicates that the majority of the intrinsic anti-tumour cell activity of ALM is due to the anti-ErbB3 A5 scFv arm. Colonies larger than $0.35 \mathrm{~mm}$ were counted using an automatic colony counter. Error bars represent the standard deviation.

Table 3 The A5-linker-ML3.9 bs-scFv arrests MDA-36I/DYT2 cells in the GI phase of the cell cycle

\% Cells in each cell cycle compartment

\begin{tabular}{lccc}
\cline { 2 - 4 } Treatment & GI & S & G2 \\
\hline Non-treated & 73.8 & 16.3 & 12.9 \\
The A5-linker-ML3.9 bs-scFv & $\mathbf{8 5 . 3}$ & $\mathbf{1 0 . 4}$ & $\mathbf{6 . 7}$ \\
Trastuzumab & 71.8 & 18.5 & 12 \\
Rituximab & 74.4 & 14.1 & 12.6 \\
\hline
\end{tabular}

aPercentage of cells in each compartment as calculated by the Dean/Jett/Fox algorithm. 
levels of both target antigens. Although the anti-ErbB2 scFv ML3.9 $\left(K_{\mathrm{D}}=1 \times 10^{-9}\right)$ was sufficient to promote binding of ALM to MVM2 cells (ErbB2' +'/ErbB3'-') at ALM concentrations above $10 \mathrm{nM}$, it should be noted that MVM2 cells express levels of ErbB2 equal to, or greater than, a number of ErbB2-positive breast cancer cells lines such as MDA-361/DYT2, T-47D and MDA-MB-231 when measured in vitro by quantitative flow cytometry (Table 1). The high level of ErbB2 on MVM2 suggests that the levels of selectivity obtained may be an underestimate of those obtainable in vivo. This argument is further supported by the selective targeting of BT-474 cells in a background of excess MCF10a cells. An alternative possibility, which is not mutually exclusive with the above hypothesis, is that the anti-ErbB2 scFv ML3.9 is driving initial ALM targeting and that bispecific binding is promoting selective retention of ALM. Such a model supports a hypothesis that the use of moderate- to low-affinity arms in the bs-scFv could significantly limit targeting of tissues that only express one of the tumour antigens, particularly when the antigen is expressed at relatively low levels. Using affinity mutants of the ML3.9 scFv, Adams et al (1998) have shown that a $K_{\mathrm{D}}$ between $10^{-7}$ and $10^{-8}$ is necessary to achieve monovalent targeting in vivo when the antigen is highly overexpressed. In an effort to optimise the targeting and therapeutic efficacy of ALM, we hypothesise that strategies to alter the affinity for either one or both of the arms for their target antigens can be used to increase the window of selective targeting achievable with bs-scFvs targeting ErbB2' + '/ErbB3'+' tumours although not impairing the overall tumour retention. We believe that the targeting selectivity exhibited by ALM, coupled with its intrinsic anti-tumour cell activity and rapid systemic clearance, makes it a potent therapeutic agent in its own right, as well as an excellent vehicle for the delivery of toxic payloads, such as chemotherapy and radionucleotides. Experiments are underway to test this hypothesis.

Targeting two tumour-associated antigens as a mechanism for modulating signalling within the tumour cell to elicit a therapeutic effect was validated by $\mathrm{Zu}$ and colleagues using a single-gene bs-diabody molecule specific for VEGFR2 (KDR) and VEGFR3 (Flt-4). This bs-diabody is capable of binding to both target receptors and blocking ligand-dependent signalling and cell migration in vitro (Jimenez et al, 2005). The group has also elaborated the bs-diabody format to create a di-diabody, a tetravalent IgG-like structure with an intact Fc-domain. A didiabody based on the $\mathrm{Vh}$ and $\mathrm{Vl}$ domains of the anti-EGFR MAb IMC-11F8 and the anti-IGFR MAb IMC- 1121 binds to both IGFR and EGFR. Similar to the parent IgG, the di-diabody blocks liganddependent signalling elicited by both EGF and IGF stimulation and promotes an ADCC response when assayed in vitro. When injected into mice harbouring IGFR'+'/EGFR'+' HT-29 tumour xenografts, the di-diabody elicits an anti-tumour response that was statistically similar to that seen in mice treated with a combination of both parent antibodies (Lu et al, 2005). Elaboration of ALM to include an intact Fc domain, similar to the di-diabody, may be useful for future derivatives of ALM to promote prolonged blood retention and greater tumour uptake, while also providing the potential for ADCC. Alternatively, strategies such as fusion to albumin-binding peptides (Dennis et al, 2002; Nguyen et al, 2006) may be sufficient to increase blood retention, while retaining the tumour penetration properties of smaller antibody fragments (Adams and Weiner, 2005).

In contrast to the di-diabody described above, ALM targets a heterodimeric pair of RTKs from a unique signal transduction pathway. Misappropriate signalling through the ErbB network promotes processes such as cell survival and is recognised as directly contributing to formation and progression of a number of commonly occurring cancers (Harari and Yarden, 2000; Hynes and Lane, 2005). Unregulated signalling is often a consequence of receptor overexpression. In breast cancer driven by gene amplification and overexpression of ErbB2, disruption of
ErbB2-dependent signalling with either trastuzumab or the small-molecule tyrosine kinase inhibitor lapatinib is correlated with clinical efficacy. The ErbB3 growth factor receptor is being increasingly recognised as a central player in ErbB2-driven breast cancer. Immunohistochemical studies have shown that ErbB3 is expressed or overexpressed in greater than $50 \%$ of DCIS and invasive breast cancers (Gasparini et al, 1994; Bobrow et al, 1997; Naidu et al, 1998) and correlates with poor prognosis (Rajkumar et al, 1996; Lee et al, 2002; Bieche et al, 2003; Witton et al, 2003; Tovey et al, 2004). As stated above, the ErbB2 and ErbB3 receptors are frequently co-expressed in human breast cancer, but potentially more indicative of the importance of ErbB2/ErbB3 heterodimers in driving breast cancer progression is the link between escape from ErbB2-targeted therapies and a gain in ErbB3 activity or expression. In patients, high levels of ErbB3 expression predict early escape from trastuzumab therapy (Smith et al, 2004), and escape of at least six different breast cancer cell lines from smallmolecule TKIs in vitro correlates with activation of ErbB3 and concomitant signalling through the Akt pathway (Sergina et al, 2007). In addition, recent evidence from Lee-Hoeflich et al (2008) demonstrated that ErbB3 was preferentially phosphorylated in ErbB2-amplified breast cancer lines and that knockdown of ErbB3 inhibited growth in vitro and in vivo. The authors postulate that the addition of pertuzumab, an anti-ErbB2 Mab that blocks ligandinduced ErbB2/ErbB3 dimerisation, to trastuzumab regimens followed at present may provide additional therapeutic benefit by inhibiting ErbB3-dependent signalling. The A5-linker-ML3.9 bs-scFv, by co-targeting this receptor pair, may be capable of a similar activity.

A number of studies strongly suggest that cross talk between ErbB2/ErbB3 heterodimer and ER receptor are responsible for development of tamoxifen resistance (Jhabvala-Romero et al, 2003; Stoica et al, 2003) and that downregulation of ErbB3 abrogates tamoxifen resistance (Liu et al, 2007). Similar studies have linked the ErbB2/ErbB3 heterodimer to the development of androgen-independent prostate cancer (Mellinghoff et al, 2004; Ghosh et al, 2005; Gregory et al, 2005; Edwards et al, 2006). Evidence from lung cancer (Engelman et al, 2007), pancreatic cancer (Frolov et al, 2007), melanoma (Reschke et al, 2008) and head and neck cancer (Erjala et al, 2006) suggest that ErbB3-dependent signalling mechanisms are important for not only disease progression, but also resistance to EGFR-targeted therapies. Together, these data support a key role for ErbB3 multiple types of cancer and suggest that effective inhibition of ErbB3 may be important for gaining complete therapeutic efficacy with ErbB inhibitors.

The anti-ErbB3 A5 scFv is responsible for the majority of the intrinsic anti-tumour activity of ALM. Despite an affinity for ErbB3 that is unable to promote rapid cell binding in either flow cytometry or in vivo targeting studies, we have shown that chronic treatment of ErbB3' ${ }^{\prime}{ }^{\prime}$ cells with A5 is sufficient to induce growth arrest. Thus, by fusing A5 into the ALM bs-scFv, we have created a vehicle that is capable of effectively targeting this therapeutic $\mathrm{scFv}$ to relevant tumour cells. Although the molecular mechanism by which A5 induces its therapeutic effect is not fully elucidated here, one potential mechanism is through blocking ligand-induced heterodimerization of ErbB3. Consistent with such a mechanism is the fact that both pertuzumab, which inhibits ErbB2/ErbB3 heterodimerization and signalling, and ALM are active preclinically against breast cancer cells that are not gene-amplified for ErbB2. This is in direct contrast to the FDA-approved MAb trastuzumab, which requires ErbB2 gene amplification.

In conclusion, we have created a bs-scFv molecule that is capable of mediating selective in vitro and in vivo tumour targeting and provided what we believe to be the first rigorous evidence of enhanced targeting selectivity by a bsAb specific for two tumourassociated antigen (TAA). The consequence of targeting tumour 
cells with ALM is effective inhibition of tumour cell growth in vitro. Taken together, our results suggest that bispecific targeting of ErbB2 and ErbB3 with ALM may be efficacious in vivo against breast cancers with a wider range of ErbB2 expression than those amenable to the trastuzumab therapy available at present. We are addressing this question at present. Moreover, these data also suggest that targeting strategies that depend upon co-expression of two TAAs such as the one used here may increase tumour-targeting specificity and decrease the normal tissue toxicities that are sometimes associated with antibody-based targeting of growth factor receptors. Furthermore, the clearance kinetics of ALM, coupled with its targeting selectivity, may make it an excellent candidate for use as an immunoconjugate for the delivery of cytotoxic agents.

\section{REFERENCES}

Adams GP, McCartney JE, Tai M-S, Oppermann H, Huston JS, Stafford WF, Bookman MA, Fand I, Houston LL, Weiner LM (1993) Highly specific in vivo tumor targeting by monovalent and divalent forms of $741 \mathrm{~F} 8$ anti-c-erbB-2 single-chain Fv. Cancer Res 53: 4026-4034

Adams GP, Schier R, Marshall K, Wolf EJ, McCall AM, Marks JD, Weiner LM (1998) Increased affinity leads to improved selective tumor delivery of single-chain Fv antibodies. Cancer Res 58: 485-490

Adams GP, Tai MS, McCartney JE, Marks JD, Stafford III WF, Houston LL, Huston JS, Weiner LM (2006) Avidity-mediated enhancement of in vivo tumor targeting by single-chain Fv dimers. Clin Cancer Res 12(5): $1599-1605$

Adams GP, Weiner LM (2005) Monoclonal antibody therapy of cancer. Nat Biotechnol 23(9): 1147-1157

Agus DB, Akita RW, Fox WD, Lewis GD, Higgins B, Pisacane PI, Lofgren JA, Tindell C, Evans DP, Maiese K (2002) Targeting ligand-activated ErbB2 signaling inhibits breast and prostate tumor growth. Cancer Cell 2(2): $127-137$

Agus DB, Sweeney CJ, Morris MJ, Mendelson DS, McNeel DG, Ahmann FR, Wang J, Derynck MK, Ng K, Lyons B, Allison DE, Kattan MW, Scher HI (2007) Efficacy and safety of single-agent pertuzumab (rhuMAb 2C4), a human epidermal growth factor receptor dimerization inhibitor, in castration-resistant prostate cancer after progression from taxane-based therapy. J Clin Oncol 25(6): 675-681

Bieche I, Onody P, Tozlu S, Driouch K, Vidaud M, Lidereau R (2003) Prognostic value of ERBB family mRNA expression in breast carcinomas. Int J Cancer 106(5): $758-765$

Bobrow LG, Millis RR, Happerfield LC, Gullick WJ (1997) c-erbB-3 protein expression in ductal carcinoma in situ of the breast. Eur J Cancer 33(11): $1846-1850$

Cunningham D, Humblet Y, Siena S, Khayat D, Bleiberg H, Santoro A, Bets D, Mueser M, Harstrick A, Verslype C, Chau I, Van Cutsem E (2004) Cetuximab monotherapy and cetuximab plus irinotecan in irinotecanrefractory metastatic colorectal cancer. $N$ Engl J Med 351(4): 337-345

de Bono JS, Bellmunt J, Attard G, Droz JP, Miller K, Flechon A, Sternberg C, Parker C, Zugmaier G, Hersberger-Gimenez V, Cockey L, Mason M, Graham J (2007) Open-label phase II study evaluating the efficacy and safety of two doses of pertuzumab in castrate chemotherapy-naive patients with hormone-refractory prostate cancer. J Clin Oncol 25(3): $257-262$

Dennis MS, Zhang M, Meng YG, Kadkhodayan M, Kirchhofer D, Combs D, Damico LA (2002) Albumin binding as a general strategy for improving the pharmacokinetics of proteins. J Biol Chem 277(38): 35035-35043

Dorvillius M, Garambois V, Pourquier D, Gutowski M, Rouanet P, Mani JC, Pugniere M, Hynes NE, Pelegrin A (2002) Targeting of human breast cancer by a bispecific antibody directed against two tumour-associated antigens: ErbB-2 and carcinoembryonic antigen. Tumor Biol 23: 337-347

Edwards J, Traynor P, Munro AF, Pirret CF, Dunne B, Bartlett JMS (2006) The role of HER1-HER4 and EGFRvIII in hormone-refractory prostate cancer. Clin Cancer Res 12(1): 123-130

Engelman JA, Zejnullahu K, Mitsudomi T, Song Y, Hyland C, Park JO, Lindeman N, Gale C-M, Zhao X, Christensen J, Kosaka T, Holmes AJ, Rogers AM, Cappuzzo F, Mok T, Lee C, Johnson BE, Cantley LC, Janne PA (2007) MET amplification leads to gefitinib resistance in lung cancer by activating ERBB3 signaling. Science 316(5827): 1039-1043

\section{ACKNOWLEDGEMENTS}

We thank LM Weiner for valuable discussions. We also thank the members of the Fox Chase Cancer Center Laboratory Animal Facility, Flow Cytometry Facility, Molecular Modeling Facility and BioTech Facility for their technical support. This work was funded, in part, by research grants from the US Army Medical Research and Material Command (DAMD17-01-1-0520, to GPA), CCSG Pilot Grant (P30CA006927, to GPA) and American Cancer Society (MRSG-08-018-01-CDD, to MKR). This project was also funded, in part, by the Bernard A and Rebecca S Bernard Foundation and a grant from the Pennsylvania Department of Health to GPA. The department specifically disclaims responsibility for any analyses, interpretations or conclusions.
Erjala K, Sundvall M, Junttila TT, Zhang N, Savisalo M, Mali P, Kulmala J, Pulkkinen J, Grenman R, Elenius K (2006) Signaling via ErbB2 and ErbB3 associates with resistance and epidermal growth factor receptor (EGFR) amplification with sensitivity to EGFR inhibitor gefitinib in head and neck squamous cell carcinoma cells. Clin Cancer Res 12(13): 4103-4111

Fraker PJ, Speck Jr JC (1978) Protein and cell membrane iodinations with a sparingly soluble chloroamide, 1,3,4,6-tetrachloro-3a, 6a-diphenylglycoluril. Biochem Biophys Res Commun 80(4): 849-857

Frolov A, Schuller K, Tzeng C-WD, Cannon EE, Ku BC, Howard H, Vickers SM, Heslin MJ, Buchsbaum DJ, Arnoletti JP (2007) ErbB3 expression and dimerization with egfr influence pancreatic cancer cell sensitivity to erlotinib. Cancer Biol Ther 6(4): 548-554

Gasparini G, Gullick WJ, Maluta S, Dalla Palma P, Caffo O, Leonardi E, Boracchi P, Pozza F, Lemoine NR, Bevilacqua P (1994) c-erbB-3 and c-erbB-2 protein expression in node-negative breast carcinoma-an immunocytochemical study. Eur J Cancer 30: 16-22

Ghosh P, Malik S, Bedolla R, Wang Y, Mikhailova M, Prihoda T, Troyer D, Kreisberg J (2005) Signal transduction pathways in adrogen-dependent and -independent prostate cancer cell proliferation. Endocr Relat Cancer 12: $119-134$

Gordon MS, Matei D, Aghajanian C, Matulonis UA, Brewer M, Fleming GF, Hainsworth JD, Garcia AA, Pegram MD, Schilder RJ, Cohn DE, Roman L, Derynck MK, Ng K, Lyons B, Allison DE, Eberhard DA, Pham TQ, Dere RC, Karlan BY (2006) Clinical activity of pertuzumab (rhuMAb 2C4), a HER dimerization inhibitor, in advanced ovarian cancer: potential predictive relationship with tumor HER2 activation status. J Clin Oncol 24(26): 4324-4332, 2006 Sep 10

Gregory C, Whang Y, McCall W, Fei X, Liu Y, Pnguta L, French F, Wilson E, Earp III H (2005) Heregulin-induced activation of HER2 and HER3 increases androgen receptor transactivation and CWR-R1 human recurrent prostate cancer cell growth. Clin Cancer Res 11: 1704-1712

Harari D, Yarden Y (2000) Molecular mechanisms underlying ErbB2/HER2 action in breast cancer. Oncogene 19: 6102-6114

Horak E, Heitner T, Robinson MK, Simmons HH, Garrison J, Russeva M, Furmanova P, Lou J, Zhou Y, Yuan QA, Weiner LM, Adams GP, Marks JD (2005) Isolation of scFvs to in vitro produced extracellular domains of EGFR family members. Cancer Biother Radiopharma 20(6): 603-613

Hynes NE, Lane HA (2005) ErbB Receptors and cancer: the complexity of targeted inhibitors. Nat Rev Cancer 5(5): $341-354$

Jhabvala-Romero F, Evans A, Guo S, Denton M, Clinton GM (2003) Herstatin inhibits heregulin-mediated breast cancer cell growth and overcomes tamoxifen resistance in breast cancer cells that overexpress HER-2. Oncogene 22: 8178-8186

Jimenez X, Lu D, Brennan L, Persaud K, Liu M, Miao H, Witte L, Zhu Z (2005) A recombinant, fully human, bispecific antibody neutralizes the biological activities mediated by both vascular endothelial growth factor receptors 2 and 3. Mol Cancer Ther 4(3): 427-434

Keler T, Graziano RF, Mandal A, Wallace PK, Fisher J, Guyre PM, Fanger MW, Deo YM (1997) Bispecific antibody-dependent cellular cytotoxicity of HER2/neu-overexpressing tumor cells by $\mathrm{Fc}$ gamma receptor type I-expressing effector cells. Cancer Res 57(18): 4008-4014

Knox SJ, Goris ML, Tempero M, Weiden PL, Gentner L, Breitz H, Adams GP, Axworthy D, Gaffigan S, Bryan K, Fisher DR, Colcher D, Horak ID, Weiner LM (2000) Phase II trial of Yttrium-90-DOTA-biotin pretargeted 
by NR-LU-10 antibody/streptavidin in patients with metastatic colon cancer. Clin Cancer Res 6(2): $406-414$

Lee JC, Wang ST, Chow NH, Yang HB (2002) Investigation of the prognostic value of coexpressed erbB family members for the survival of colorectal cancer patients after curative surgery. Eur J Cancer 38(8): $1065-1071$

Lee-Hoeflich ST, Crocker L, Yao E, Pham T, Munroe X, Hoeflich KP, Sliwkowski MX, Stern HM (2008) A central role for HER3 in HER2-amplified breast cancer: implications for targeted therapy. Cancer Res 68: 5878 - 5887

Lewis GD, Figari I, Fendly B, Wong WL, Carter P, Gorman C, Shepard HM (1993) Differential responses of human tumor cell lines to anti-p185HER2 monoclonal antibodies. Cancer Immunol Immunother 37(4): $255-263$

Liu B, Ordonez-Ercan D, Fan Z, Edgerton SM, Yang X, Thor AD (2007) Downregulation of erbB3 abrogates erbB2-mediated tamoxifen resistance in breast cancer cells. Int J Cancer 120(9): 1874-1882

Lu D, Zhang H, Koo H, Tonra J, Balderes P, Prewett M, Corcoran E, Mangalampalli V, Bassi R, Anselma D, Patel D, Kang Z, Ludwig DL, Hicklin DJ, Bohlen P, Witte L, Zhu Z (2005) A fully human recombinant IgG-like bispecific antibody to both the epidermal growth factor receptor and the insulin-like growth factor receptor for enhanced antitumor activity. J Biol Chem 280(20): 19665-19672

Mellinghoff I, Vivanco I, Kwon A, Tran. C, Wongvipat J, Sawyers C (2004) HER2/neu kinase-dependent modulation of androgen receptor function through effects on DNA binding and stability. Cancer Cell 6: 517-527

Molhoj M, Crommer S, Brischwein K, Rau D, Sriskandarajah M, Hoffmann P, Kufer P, Hofmeister R, Baeuerle PA (2007) CD19-/CD3-bispecific antibody of the BiTE class is far superior to tandem diabody with respect to redirected tumor cell lysis. Mol Immunol 44(8): 1935-1943

Naidu R, Yadav M, Nair S, Kutty MK (1998) Expression of c-erbB3 protein in primary breast carcinomas. Brit J Cancer 78(10): 1385-1390

Nguyen A, Reyes II AE, Zhang M, McDonald P, Wong WL, Damico LA, Dennis MS (2006) The pharmacokinetics of an albumin-binding Fab (AB.Fab) can be modulated as a function of affinity for albumin. Protein Eng Des Sel 19(7): $291-297$

Pai LH, Bookman MA, Ozols RF, Young RC, Smith II JW, Longo DL, Gould B, Frankel A, McClay EF, Howell S (1991) Clinical evaluation of intraperitoneal Pseudomonas exotoxin immunoconjugate OVB3-PE in patients with ovarian cancer. J Clin Oncol 9: 2095-2103

Pegram M, Hsu S, Lewis GD, Pietras R, Beryt M, Sliwkowski M, Coombs D, Baly D, Kabbinavar F, Slamon D (1999) Inhibitory effects of combinations of HER-2/neu antibody and chemotherapeutic agents used for treatment of human breast cancers. Oncogene 18(13): $2241-2251$

Rajkumar T, Stamp GWH, Hughes CM, Gullick WJ (1996) c-erbB3 protein expression in ovarian cancer. Clin Mol Pathol 49(4): M199-M202

Reschke M, Mihic-Probst D, van der Horst EH, Knyazev P, Wild PJ, Hutterer M, Meyer S, Dummer R, Moch H, Ullrich A (2008) HER3 is a determinant for poor prognosis in melanoma. Clin Cancer Res 14(16): $5188-5197$

Robinson MK, Doss M, Shaller C, Narayanan D, Marks JD, Adler LP, Gonzalez Trotter DE, Adams GP (2005) Quantitative immuno-positron emission tomography imaging of HER2-positive tumor xenografts with an iodine-124 labeled anti-HER2 diabody. Cancer Research 65(4): 1471 - 1478

Schier R, Bye J, Apell G, McCall A, Adams GP, Malmqvist M, Weiner LM, Marks JD (1996) Isolation of high-affinity monomeric human anti-c-erbB2 single chain Fv using affinity-driven selection. J Mol Biol 255: 28-43

Seidman A, Hudis C, Pierri MK, Shak S, Paton V, Ashby M, Murphy M, Stewart SJ, Keefe D (2002) Cardiac dysfunction in the trastuzumab clinical trials experience. J Clin Oncol 20: 1215-1221

Sergina NV, Rausch M, Wang D, Blair J, Hann B, Shokat KM, Moasser MM (2007) Escape from HER-family tyrosine kinase inhibitor therapy by the kinase-inactive HER3. Nature 445: 437-441

Shahied LS, Tang Y, Alpaugh RK, Somer R, Greenspon D, Weiner LM (2004) Bispecific minibodies targeting HER2/neu and CD16 exhibit improved tumor lysis when placed in a divalent tumor antigen binding format. J Biol Chem 279(52): 53907-53914

Shalaby MR, Shepard HM, Presta L, Rodrigues ML, Beverley PC, Feldmann M, Carter P (1992) Development of humanized bispecific antibodies reactive with cytotoxic lymphocytes and tumor cells overexpressing the HER2 protooncogene. J Exp Med 175(1): 217-225

Slamon DJ, Godolphin W, Jones LA, Holt JA, Wong SG, Keith DE, Levin WJ, Stuart SG, Udove J, Ullrich A, Press MF (1989) Studies of the HER-2/ neu proto-oncogene in human breast and ovarian cancer. Science 244(4905): $707-712$

Slamon DJ, Leyland-Jones B, Shak S, Fuchs H, Paton V, Bajamonde A, Fleming T, Eiermann W, Wolter J, Pegram M, Baselga J, Norton L (2001) Use of chemotherapy plus a monoclonal antibody against HER2 for metastatic breast cancer that overexpresses HER2. N Engl J Med 344(11): $783-792$

Smith BL, Chin D, Maltzman W, Crosby K, Hortobagyi GN, Bacus SS (2004) The efficacy of Herceptin therapies is influenced by the expression of other erbB receptors, their ligands and the activation of downstream signalling proteins. Brit J Cancer 91: 1190 - 1194

Stoica GE, Franke TF, Wellstein A, Morgan E, Czubayko F, List H-J, Reiter R, Martin MB, Stoica A (2003) Heregulin-b1 regulates the estrogen receptor-alpha gene expression and activity via the ErbB2/PI 3-K/Akt pathway. Oncogene 22: 2073-2087

Tang Y, Lou J, Alpaugh RK, Robinson MK, Marks JD, Weiner LM (2007) Regulation of antibody-dependent cellular cytotoxicity by IgG intrinsic and apparent affinity for target antigen. J Immunol 179(5): 2815-2823

Tovey SM, Witton CJ, Bartlett JM, Stanton PD, Reeves JR, Cooke TG (2004) Outcome and human epidermal growth factor receptor (HER) $1-4$ status in invasive breast carcinomas with proliferation indices evaluated by bromodeoxyuridine labelling. Breast Cancer Res 6(3): 246-251

Valone FH, Kaufman PA, Guyre PM, Lewis LD, Memoli V, Deo Y, Graziano R, Fisher JL, Meyer L, Mrozek-Orlowski M (1995) Phase Ia/Ib trial of bispecific antibody MDX-210 in patients with advanced breast or ovarian cancer that overexpresses the proto-oncogene HER-2/neu. J Clin Oncol 13(9): $2281-2292$

Walshe JM, Denduluri N, Berman AW, Rosing DR, Swain SM (2006) A phase II trial with trastuzumab and pertuzumab in patients with HER2overexpressed locally advanced and metastatic breast cancer. Clin Breast Cancer 6(6): 535-539

Weiner LM, Clark JI, Davey M, Li WS, Garcia de Palazzo I, Ring DB, Alpaugh RK (1995) Phase I trial of 2B1, a bispecific monoclonal antibody targeting C-erbB-2 and Fc gamma RIII. Cancer Res 55(20): 4586-4593

Weiner LM, Holmes M, Richeson A, Godwin A, Adams GP, Hsieh-Ma ST, Ring DB, Alpaugh RK (1993) Binding and cytotoxicity characteristics of the bispecific murine monoclonal antibody 2B1. J Immunol 151(5): $2877-2886$

Witton CJ, Reeves JR, Going JJ, Cooke TG, Bartlett JM (2003) Expression of the HER1-4 family of receptor tyrosine kinases in breast cancer. $J$ Pathol 200(3): $290-297$

Yakes FM, Chinratanalab W, Ritter CA, King W, Seelig S, Arteaga CL (2002) Herceptin-induced inhibition of phosphatidylinositol-3 kinase and Akt is required for antibody-mediated effects on p27, cyclin D1, and antitumor action. Cancer Res 62(14): 4132-4141

Yang D, Kuan C, Payne J, Kihara A, Murray A, Wang L, Alimandi M, Pierce J, Pastan I, Lippman M (1998) Recombinant heregulin-Pseudomonas exotoxin fusion proteins: interactions with the heregulin receptors and antitumor activity in vivo. Clin Cancer Res 4(4): 993-1004

Yarden Y, Sliwkowski MX (2001) Untangling the ErbB signaling network. Nat Rev Mol Biol 2: 127-137

Yoshino I, Peoples GE, Goedegebuure PS, Maziarz R, Eberlein TJ (1994) Association of HER2/neu expression with sensitivity to tumor-specific CTL in human ovarian cancer. I Immunol 152: 2393-2400

Yuan QA, Simmons HH, Robinson MK, Russeva M, Marasco WA, Adams GP (2006) Development of engineered antibodies specific for the Mullerian inhibiting substance type II receptor: a promising candidate for targeted therapy of ovarian cancer. Mol Cancer Ther 5(8): 2096-2105 